\title{
Germination of seeds of big and bottlebrush squirreltail
}

\author{
JAMES A. YOUNG,* CHARLIE D. CLEMENTS, AND TOM JONES
}

Authors are Range Scientists, USDA-ARS, 920 Valley Road, Reno, Nev. 89512 and Research Geneticist, USDA-ARS, Forage and Range Research Laboratory, Utah State University, Logan, Utah 84322-6300. *E-mail for corresponding author: jayoung@ unr.nevada.edu

Abstract

Bottlebrush squirreltail [Elymus elymoides (Raf.) Swezey] and big squirreltail [E. multisetus (J. G. Smith) Burtt Davy] are short-lived perennial bunchgrasses found on rangelands from the Pacific Coast to the Great Plains and from Canada to Mexico. They are highly variable species with several subspecies described for bottlebrush squirreltail. In many rangeland communities, bottlebrush squirreltail is the transitional dominant native grass in secondary successional communities. There is considerable interest in using squirreltail species in rangeland restoration seedings, but problems with seed collection (disarticulating rachis) have kept seed prices very high. Recently, grass geneticists have begun to develop lines of squirreltail for release as pre-varietal germplasm. Our purpose was to compare the germination at a wide range of constant or alternating temperatures of squirreltail seeds from developmental lines and material collected from native stands. Big and bottlebrush squirreltail seeds (caryopses) germinated over a wide range of temperatures. Seeds of bottlebrush squirreltail produced from the same stand in 3 different years had remarkably similar germination temperature profiles. The greatest variation in germination among accessions occurred at very cold and cold categories of seedbed temperatures. These differences may be very significant in the establishment of seedlings in the field. There was no one temperature regime that always supported optimum germination for all of the squirreltail accessions tested. The regimes most frequently supporting optimum germination were $15 / 20$ and $15 / 25^{\circ} \mathrm{C}$. The seeds of big and bottlebrush squirreltail tested do not have the ecological amplitude of seeds of the competitive exotic weed cheatgrass (Bromus tectorum $\mathrm{L}$.), but they come close.

Key Words: Elymus elymoides, Elymus multisetus, incubation temperatures, germination profiles, cheatgrass

For many years range managers knew bottlebrush squirreltail [Elymus elymoides (Raf.) Swezey] by the scientific name of Sitanion hystrix (Nutt.) J. G. Smith. Big squirreltail [E. multisetus (J. G. Smith) Burtt Davy] originally known as S. jubatum J. G. Smith, is a less widely recognized species, and probably often confused with bottlebrush squirreltail (Hitchcock 1950). For a long time it has been recognized that squirreltail plants are closely related to the genus Pseudoroegneria and Elymus (Cronquist et al. 1977). Many natural hybrids have been recognized with squirreltail considered to be one parent (Wilson 1963). The taxonomic reshuffling is a result of vastly improved understanding of the

Manuscript accepted 4 Aug. 2002.
Resumen

"Bottlebrush squirreltail" [Elymus elymoides (Raf.) Swezey] y "Big squirreltail" [E. multisetus (J. G. Smith) Burtt Davy] son zacates amacollados perennes de vida corta que se encuentran en los pastizales, desde la Costa del Pacifico hasta las Grandes Planicies y desde Canadá hasta México. Estas especies son altamente variables con varias subespecies descritas para "Bottlebrush squirreltail". En muchas comunidades de pastizal, en sucesión secundaria, el "Bottlebrush squirreltail" es el zacate nativo transicional dominate. Hay un considerable interés en usar especies de "Squirreltail" en siembras para restaurar pastizales, pero problemas con la colección de semilla (desarticulación del raquis) han mantenido los precios de la semilla muy altos. Recientemente los genetistas de pastos han iniciado el desarrollo de líneas de "Squirreltail" para liberarlas como germoplasma pre-varietal. Nuestro propósito fue comparar la germinación de semillas de las líneas de "Squirreltail" en desarrollo y material colectado de poblaciones nativas bajo un amplio rango de temperaturas constantes o alternadas. Las semillas (cariposides) de "Big squirreltail" y "Bottlebrush squirreltail" germinaron en un amplio rango de temperaturas. Semillas de "Bottlebrush squirreltail" producidas en la misma población, pero en tres diferentes años, tuvieron perfiles de temperatura de germinación remarcablemente similares. La mayor variación en germinación entre las accesiones evaluadas ocurrió en las categorías de temperatura de la cama de siembra de frias y muy fria. Estas diferencias pueden ser muy significativas en el establecimiento de plántulas en el campo. No hubo un régimen de temperatura que mantuviera siempre la germinación óptima para todas las accesiones de "Squirreltail" evaluadas. Los regímenes que más frecuentemente mantuvieron la geminación óptima fueron 15/20 y $15 / 25^{\circ} \mathrm{C}$. Las semillas evaluadas de "Big squirreltail" $y$ "Bottlebrush squirreltail" no tienen la amplitud ecológica de las semillas de la maleza exótica "Cheatgrass" (Bromus tectorum L.), sin embargo ellas están muy cerca.

genetics of the grass tribe Triticeae and the introduction of molecular biochemical techniques to determine affinities (Barkworth 1993).

In the Intermountain Area, temperatures for plant growth and soil moisture to support such growth are nearly completely out of phase (Evans et al. 1970). Moisture occurs during the cold winter months and the summers are nearly dry. Plants that germinate at very cold seedbed temperatures have the opportunity to establish before the late spring and summer drought. Cheatgrass (Bromus tectorum L.) closes plant communities to the establishment of perennial grass seedlings through competition for soil moisture (Evans et al. 1970). This competitive advantage is enhanced by 
the inherent potential to germinate at very low seedbed temperatures (Young and Evans 1982).

In a previous study we developed germination temperature profiles for seeds of bottlebrush squirreltail collected from native stands (Young and Evans 1977). In that study seeds were collected from the same stand for 3 years over a 4 year period. The average germination of seeds of this material was published, but the profiles for individual years were not published.

Our purpose was to compare the germination temperature profiles from this previous work with one developed for a native stand collection that we have successfully used to establish stands on harsh sites in Nevada, and with developmental lines used in the grass improvement program of the third author. All of these accessions of squirreltail are compared to cheatgrass.

\section{Materials and Methods}

Seeds of bottlebrush squirreltail were collected in 1972, 1974, and 1975 from a stand located at Medell Flat $30 \mathrm{~km}$ north of Reno, Nev. (Lat. 39 38', Long. 140 ${ }^{\circ}$ $\left.19^{\prime}\right)$. This collection is considered to be Elymus elymoides ssp. elymoides (Raf.) Swezey. There was no seed production in 1973. The seeds from several hundred plants growing in a previously burned big sagebrush (Artemisia tridentata Nutt.) site were collected. The seeds were threshed by hand, cleaned, and stored at room temperature for 90 days before testing. A second source from native stands was collected for us in White Pine County, Nev. (Lat. $39^{\circ} 10^{\prime}$, Long. $114^{\circ} 15^{\prime}$ ) in 1999 by a commercial seed dealer. This collection is also considered to be E. elymoides ssp. elymoides. We sampled from a $50 \mathrm{~kg}$ seed lot to obtain the seeds for laboratory testing. This collection, identified as White Pine, has been successfully seeded at several locations in the northern Great Basin (unpublished research, USDA, ARS, Reno, Nev.).

The Forage and Range Research Laboratory, USDA, ARS, Logan, Utah received 36 accessions of squirreltail in 1993 from the USDA, National Resource Conservation Service (NRCS), Plant Material Center, Aberdeen, Ida. This material had been collected from California, Colorado, Idaho, Montana, Nevada, Oregon, Utah, and Washington. The material was planted at the Greenville Farm experimental site north of Logan, Utah (Lat. $41^{\circ} 54^{\prime}$, Long. $111^{\circ} 50^{\prime}$ ). The squirreltail accessions were evaluated for seed production and heading date. The accession with the highest seed yield and weight was Sand Hollow (Lat. $43^{\circ} 51^{\prime}$, Long. $116^{\circ} 51^{\prime}$ ) a big squirreltail (Jones et al. 1998). Sand Hollow has been released as a pre-variety germplasm (natural tract).

A second accession of big squirreltail (Dietrich) was collected near Dietrich, Ida. (Lat. 42 ${ }^{\circ}$ 54', Long. $114^{\circ} 19^{\prime}$ ) in 1995. It has been tested in experiments located at the Greenville experimental site and it was from these plantings that we obtained the seed for laboratory testing. This accession is not proposed for release at this time. A bottlebrush squirreltail accession (Fish Creek) was collected near Carey, Ida. (Lat.43 ${ }^{\circ} 21^{\prime}$, Long. $113^{\circ} 52^{\prime}$ ) in 1995 and grown in experiments at Greenville from which we obtained seed for testing. It is proposed for release as a pre-variety germplasm.

In all experiments 4 replications of 25 seeds each were used in a randomized block design. Seeds were placed on top of non-toxic commercial germination paper in closed Petri dishes and kept wet with tap water. Germination trials were conducted in the dark. Incidental light was received during initial wetting and germination counts. Seeds were considered germinated when the radical emerged $1 \mathrm{~mm}$. Germination counts were made after 1, 2, and 4 weeks. Constant incubation temperatures were 0,2 , and $5^{\circ} \mathrm{C}$ and at 5 degree increments through $40^{\circ} \mathrm{C}$. Alternating regimes included 16 hours at each constant temperature, plus 8 hours at each possible higher temperature per 24 hours. For example, $35 \mathrm{C}$ alternated with $40^{\circ} \mathrm{C}$ only, while $0^{\circ} \mathrm{C}$ alternated with $2,5,10$, $15,20,25,30,35$, and $40^{\circ} \mathrm{C}$. This made a total of 55 constant and alternating temperature regimes (Young et al. 1991).

The germination responses of the accessions of squirreltail accessions were compared using the following seedbed temperature regime definitions (Evans et al. 1982, Young and Evans 1982):

a. Very cold: $0 / 0$ (constant $\left.0^{\circ} \mathrm{C}\right), 0 / 2\left(0^{\circ}\right.$ $\mathrm{C}$ for 16 hours and $2^{\circ} \mathrm{C}$ for 8 hours in each 24 hours), $0 / 5$ and $2 / 2^{\circ} \mathrm{C}$.

b. Cold: $0 / 10,0 / 15,2 / 5,2 / 10,2 / 15,5 / 5$, and $5 / 10^{\circ} \mathrm{C}$.

c. Cold fluctuating: $0 / 20$ through $0 / 40^{\circ} \mathrm{C}$ and $2 / 20$ through $2 / 40^{\circ} \mathrm{C}$.

d. Fluctuating: $5 / 35$ through $5 / 40^{\circ} \mathrm{C}$, $10 / 35,10 / 40$, and $15 / 40^{\circ} \mathrm{C}$.

e. Moderate: $5 / 20$ through $5 / 30,10 / 10$ through $10 / 30^{\circ} \mathrm{C}, 15 / 15$ through $15 / 35^{\circ} \mathrm{C}, 20 / 20$ through $30 / 35^{\circ} \mathrm{C}$, and $25 / 25$ through $25 / 30^{\circ} \mathrm{C}$

f. Warm: $20 / 40,25 / 35$, and $25 / 40^{\circ} \mathrm{C}$, $30 / 30$ through $30 / 40^{\circ} \mathrm{C}, 35 / 35,35 / 40$, and $40 / 40^{\circ} \mathrm{C}$.

The temperature categories reflect germination environments of field seedbeds based on several years of monitoring in the Great Basin (Evans et al. 1970, Evans and Young 1970, 1972).

Data from each base temperature and its alternating temperature regimes were used

Table 1. Germination parameters calculated from quadratic response surfaces (Young and Evans 1982).

\begin{tabular}{|c|c|c|}
\hline Calculated parameter & Derived parameter & Purpose \\
\hline \multicolumn{3}{|l|}{ Calculated within profile } \\
\hline Mean germination & $\underset{55}{\text { Sum }}$ & Gross comparison of profiles \\
\hline Percentage of regimes with germination & $\frac{\text { Number with germination }}{55}$ & Indication of breath of germination response \\
\hline $\begin{array}{l}\text { Percentage of regimes with optimum } \\
\text { germination }\end{array}$ & $\begin{array}{l}\text { Number of regimes with germination no less than } \\
\text { maximum observed minus confidence interval }\end{array}$ & $\begin{array}{l}\text { Indication of breath of temperatures that } \\
\text { Support optimum germination }\end{array}$ \\
\hline Mean of optima & $\frac{\text { Sum of optima }}{\text { Number of optima regimes }}$ & $\begin{array}{l}\text { Provides measure of potential germination at } \\
\text { adapted temperatures }\end{array}$ \\
\hline Maximum germination & Highest observed germination & Indication of potential viability \\
\hline $\begin{array}{l}\text { Calculated among germination profiles } \\
\text { Frequency of optima }\end{array}$ & $\frac{\text { Times temperature regime supports optima }}{\text { Total number of profiles }}$ & $\begin{array}{l}\text { Provides an estimate of optimum temperatures } \\
\text { For germination with statistical precision }\end{array}$ \\
\hline
\end{tabular}


Table 2. Mean germination \pm one half of the confidence interval at the 0.01 level of probability for seeds of the Medell Flat, Nevada, 1972 accession of bottlebrush squirreltail. Seeds incubated for 4 weeks at constant or alternating temperatures from 0 through $40^{\circ} \mathrm{C}^{1}$

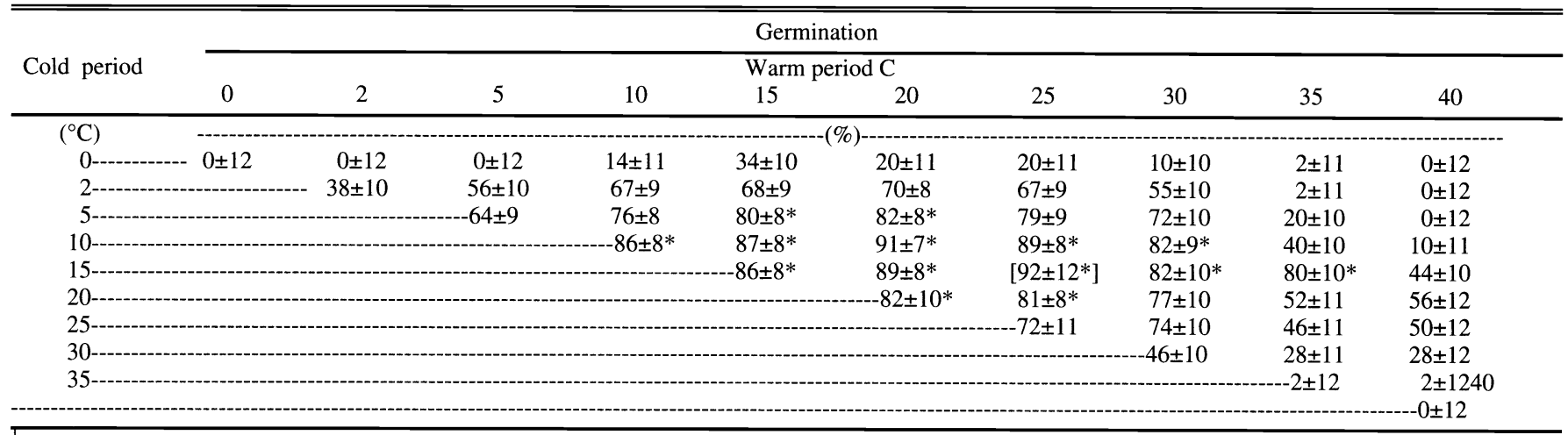

* Indicates temperature regimes with optimum germination. [ ] Encloses maximum observed germination.

to generate a quadratic response surface with estimated means and confidence intervals at the $1 \%$ level of probability (Young et al. 1980, Evans et al. 1982, Palmquist et al. 1987). A number of germination parameters were calculated from the quadratic response surfaces (Table 1) (Young and Evans 1982). These germination parameters were individually subjected to analysis of variance and the means separated by Duncan's Multiple Range Test.

\section{Results and Discussion}

A germination quadratic response surface is provided as an example of the basic data set for bottlebrush squirreltail seeds (Table 2). Germination is estimated with a confidence interval at the 0.01 level of probability for each of the 55 temperatures tested. Temperature regimes supporting optimum germination (defined in Table 1), are marked. The value of this data set is it provides an estimate of the variability that was observed in germination response for a given population of squirreltail seeds over 3 years of production. The 3 years of seed production were remarkably uniform in virtually every parameter examined (Table 3). Mean germination varied among years by only $3 \%$. Temperature regimes with some germination did not vary among years. This is an important parameter because it is an indication of the extremes at which some level of germination can be expected. In the Intermountain Area where precipitation is almost completely out of phase with temperatures for plant growth (Evans et al. 1970), germination of $38 \pm 10 \%$ at a constant $2^{\circ} \mathrm{C}$ (Table 2) may be significant biologically despite that level of germination being a long way from the maximum of $92 \pm 12 \%$ germination observed for that collection of bottle- brush squirreltail seeds. Maximum germination was observed at temperature regimes of $10 / 20\left(10^{\circ} \mathrm{C}\right.$ for 16 hours and 20 for 8 hours in each 24 hour period), $10 / 25,15 / 20$, and $15 / 25^{\circ} \mathrm{C}$. The maximum germination was over $90 \%$ for all 3 years. For a seed collected in the wilds, this is an exceptional level of viability (Young and Evans 1982).

The 3 years of bottlebrush squirreltail production exhibited the greatest variation in germination at the seedbed temperature category of very cold (Table 3 ). Germination only occurred with the seed collected in 1972 and only at a constant $2^{\circ}$ C. For the seeds produced in 1974 and 1975 no germination occurred in this category of seedbed temperatures. These are the temperatures that occur in the interface between snow cover and the mineral soil or in the very early spring in the

Intermountain Area (Evans et al. 1970). In interpreting these results, remember these 3 collections were made over a 4 year period. During the very dry year of 1973 , there was no bottlebrush squirreltail seed production from the Medell Flat stand. Perhaps, the germination response for the 3 years of seed production was so uniform because bottlebrush squirreltail is an extreme ephemeral species. Evidence of how early in the spring bottlebrush squirreltail completes its life cycle is provided by a previous study. In studies conducted at the Medell Flat collection site, we determined that if you were going to lower the apparent carbohydrate reserves of this accession of squirreltail you had to apply defoliation treatments in the very early spring, a month or 6 weeks earlier than for other perennial grasses (Young and Evans 1978).

Table 3. Germination parameters calculated from germination-temperature profiles for 3 collections of bottlebrush squirreltail from the same site (Medell Flat, Nevada) over a 4 year period. There was not sufficient seed production for collection in 1973. Data presented by Young and Evans (1977) as average not by individual years.

\begin{tabular}{lccc}
\hline \hline $\begin{array}{l}\text { Germination } \\
\text { parameter }\end{array}$ & \multicolumn{3}{c}{ Year of seed production } \\
\hline Profile mean & 1972 & 1974 & 1975 \\
Regimes with some & 37 & 35 & 34 \\
$\quad$ germination & 87 & 87 & 87 \\
Mean of optima & 85 & 89 & 91 \\
Regimes with optima & 25 & 22 & 26 \\
Maximum germination & 92 & 94 & 96 \\
Regimes with maxima & $15 / 25^{\circ} \mathrm{C}$ & $15 / 20^{\circ} \mathrm{C}$ & $10 \& 15 / 20^{\circ} \mathrm{C}$
\end{tabular}

Seedbed temperature categories

$\begin{array}{lccc}\text { Very cold } & 10 \mathrm{a} & 0 \mathrm{~b} & 0 \mathrm{~b} \\ \text { Cold } & 56 & 51 & 43 \\ \text { Cold fluctuating } & 25 & 24 & 20 \\ \text { Fluctuatin } & 23 & 27 & 33 \\ \text { Warme } & 29 & 29 & 27 \\ \text { Moderat } & 80 & 78 & 81\end{array}$

The only statistical significant difference among the 3 collections was for germination at the very cold category of seedbed temperatures where means followed by the same letter are not significantly different at the 0.01 level of probability 
Table 4. Germination parameters calculated from germination-temperature profiles for all accessions of bottlebrush and big squirreltail and a comparison with a profile for cheatgrass. ${ }^{1}$

\begin{tabular}{|c|c|c|c|c|c|c|}
\hline \multirow{3}{*}{$\begin{array}{l}\text { Germination } \\
\text { parameter }\end{array}$} & \multicolumn{4}{|c|}{ Accession } & \multirow[b]{2}{*}{ Sand } & \multirow{3}{*}{ Cheatgrass $^{3}$} \\
\hline & $\begin{array}{l}\text { Medell }^{2} \\
\text { Flat }\end{array}$ & $\begin{array}{l}\text { White } \\
\text { Pine }\end{array}$ & $\begin{array}{c}\text { Fish } \\
\text { Creek }\end{array}$ & $\begin{array}{l}\text { Deitrich } \\
\text { Hollow }\end{array}$ & & \\
\hline & \multicolumn{3}{|c|}{ Bottlebrush squirreltail } & \multicolumn{2}{|c|}{ Big squirreltail } & \\
\hline Profile mean & $35 \mathrm{bc}$ & $37 \mathrm{bc}$ & $47 b$ & $33 \mathrm{bc}$ & $26 c$ & $73 a$ \\
\hline $\begin{array}{l}\text { Regimes with } \\
\text { germination }\end{array}$ & & & & & & \\
\hline germination & $87 \mathrm{bc}$ & $98 \mathrm{ab}$ & $78 \mathrm{bc}$ & $75 \mathrm{c}$ & $76 \mathrm{c}$ & $100 \mathrm{a}$ \\
\hline Mean of optima & $88 \mathrm{~b}$ & $82 \mathrm{~b}$ & $96 a$ & $85 \mathrm{~b}$ & $78 \mathrm{c}$ & $97 \mathrm{a}$ \\
\hline Regimes with optima & $24 \mathrm{~b}$ & $4 \mathrm{c}$ & $26 \mathrm{~b}$ & $13 \mathrm{c}$ & $7 \mathrm{c}$ & $35 \mathrm{a}$ \\
\hline Maximum germination & 94ab & $85 b$ & $100 \mathrm{a}$ & $93 \mathrm{ab}$ & $84 b$ & $100 \mathrm{~b}$ \\
\hline \multicolumn{7}{|l|}{$\begin{array}{l}\text { Seedbed temperature } \\
\text { categories }\end{array}$} \\
\hline Very cold & $3 \mathrm{c}$ & $18 \mathrm{~b}$ & $0 \mathrm{c}$ & $9 \mathrm{c}$ & $0 \mathrm{c}$ & $37 \mathrm{a}$ \\
\hline Cold & $50 \mathrm{~b}$ & $57 \mathrm{~b}$ & $26 c$ & $12 \mathrm{~d}$ & $6 \mathrm{~d}$ & $72 a$ \\
\hline Cold fluctuating & $23 \mathrm{c}$ & $32 \mathrm{c}$ & $45 \mathrm{~b}$ & $37 \mathrm{~b}$ & $20 \mathrm{c}$ & $89 \mathrm{a}$ \\
\hline Fluctuating & $28 \mathrm{c}$ & $24 \mathrm{c}$ & $43 b$ & $28 \mathrm{c}$ & $29 \mathrm{c}$ & $90 \mathrm{a}$ \\
\hline Warmer & $28 \mathrm{c}$ & $33 \mathrm{c}$ & $76 a$ & $52 \mathrm{~b}$ & $37 \mathrm{c}$ & $57 \mathrm{a}$ \\
\hline Moderate & $80 \mathrm{a}$ & $60 \mathrm{~b}$ & $90 \mathrm{a}$ & $69 \mathrm{~b}$ & $63 \mathrm{~b}$ & $94 a$ \\
\hline
\end{tabular}

Means within rows followed by the same letter are not significantly different at the 0.01 level of probability as determined by Duncan's Multiple Range Test.

${ }^{2}$ Mean of 3 years production from same site.

${ }^{3}$ Cheatgrass data from Young and Evans 1982.

Comparing all the profiles for big and bottlebrush squirreltail (Table 4), reveals the mean profile germination is quite similar with the only significant $(\mathrm{P} \leq 0.01)$ difference between Fish Creek bottlebrush and Sand Hollow big squirreltail. Fish Creek had the highest and Sand Hollow the lowest mean germination observed. The 2 accession of bottlebrush squirreltail seed harvested from native stands had germination at the highest percentage of the 55 temperature regimes tested. Mean optimum germination was above $80 \%$ for all accessions tested except Sand Hollow big squirreltail. The maximum observed germination exceeded $90 \%$ except White Pine bottlebrush and Sand Hollow big squirreltail. The maximum germination for the Fish Creek accession of bottlebrush squirreltail was $100 \%$. This indicates that all of these seed lots contained highly viable seeds with little or no evidence of seed dormancy.

Table 5. Frequency that temperature regimes supported optimum germination for temperaturegermination profiles for accessions of bottlebrush and big squirreltail.

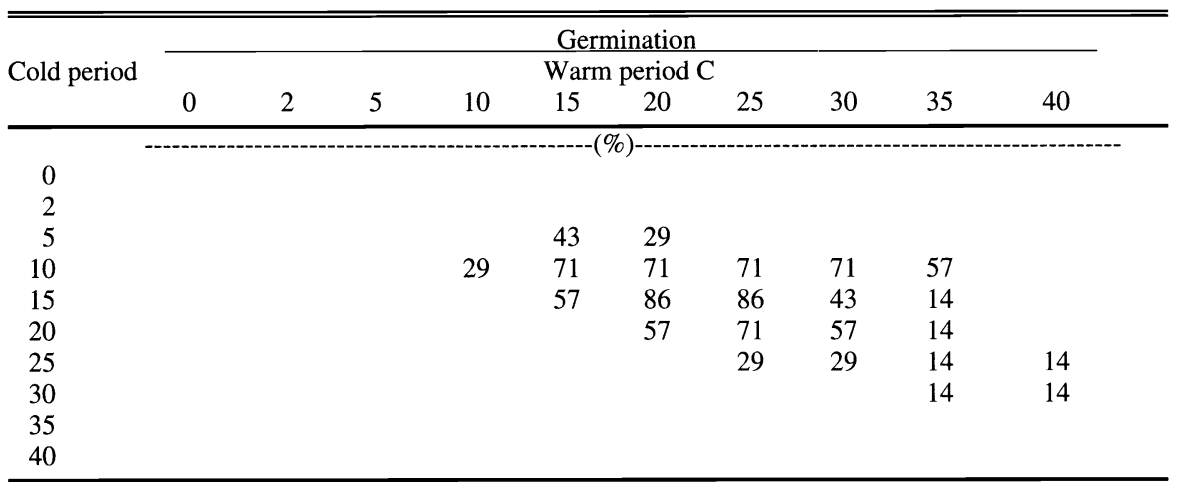

because of higher germination at $0 / 30$ and $2 / 30^{\circ} \mathrm{C}$ regimes than other accessions (data not shown). This is a very wide range of diurnal fluctuation.

The Fish Creek accession had much higher germination at warmer incubation temperatures (Table 4). Perhaps, the higher germination observed at cold fluctuating and fluctuating regimes is not only due to tolerance to wide diurnal fluctuations in incubation temperatures, but also for a tolerance to germinate at higher incubation temperatures. Fish Creek and Medell Flat were clearly the highest germinating accessions at moderate incubation temperatures, which constitute $36 \%$ of the temperature regimes tested.

Cheatgrass is the highly competitive exotic weed that limits the establishment of seedlings of native perennial grasses on Intermountain Area rangelands (Young et al. 1987). At first glance it appears that the germination of cheatgrass seeds is markedly better than for squirreltail seeds in every category (Table 4). There are 3 factors that modify this assumption. In comparison to the germination of other native perennial grasses, the accessions of big and bottlebrush squirreltail are at least distantly close to the same potential as cheatgrass (Young and Evans 1982). The germination potential of seeds of many perennial grasses native to the Intermountain Area is much lower that what we report for big and bottlebrush squirreltail. There is no evidence of dormancy in seeds of squirreltail tested. The squirreltail seeds tested from either native stands or from nurseries, have high levels of viability.

On the negative side in this comparison, is the shear magnitude of cheatgrass germination (Table 4). The cheatgrass profile averaged $73 \%$ germination, while the best squirreltail profile averaged $47 \%$ and the poorest profile averaged $26 \%$. For cheatgrass germination, $35 \%$ of the 55 temperature regimes tested supported germination not lower that the maximum observed $(100 \%)$, minus one half the confidence internal at the 0.01 level of probability. Cheatgrass germinated at all of the 55 temperatures tested. This means germination occurred at a constant $0^{\circ} \mathrm{C}, 40^{\circ} \mathrm{C}$ and $0 / 40^{\circ} \mathrm{C}$. Cheatgrass has much higher germination at very cold and cold categories of seedbed temperatures.

No single temperature regime always supported optimum germination for the seeds of all of the accessions of squirreltail tested (Table 5). The regimes with the highest frequency of optima were 15/20 and $15 / 25^{\circ} \mathrm{C}$. Temperature regimes that 
supported optimum germination at least once ranged from a constant $10^{\circ} \mathrm{C}$ to $25 / 40^{\circ} \mathrm{C}$.

The use of big or bottlebrush squirreltail accessions in restoration seedings is not limited by seed dormancy, lack of viability, or restrictive temperature requirements. Squirreltail seeds do not have the ecological amplitude for germination in comparison to seeds of cheatgrass, but they probably come as close as any native perennial grass in the Intermountain Area. The developmental selection work that so far has been done on accessions of squirreltail has been for seed production and weight, not on the basis of germination characteristics. Obviously, if you seed bottlebrush or big squirreltail accessions on sites infested with cheatgrass, weed control is necessary during site preparation.

\section{Literature Cited}

Barkworth, M. 1993. Elymus. p. 1254. In: J. C. Hickman (ed.) The Jepson Manual. Univer. California Press, Berkeley, Calif.
Cronquist A., A.H. Holmgren, N.H. Holmgren, J.L. Reveal, and P.K. Holmgren. 1977. Intermountain Flora. Vol. 6. Columbia Univer. Pres. New York, N.Y.Evans, R.A. and J.A. Young. 1970. Plant litter and establishment of alien annual species in rangeland communities. Weed Sci. 18:697-703.

Evans, R.A. and J.A. Young. 1972. Microsite requirements for establishment of alien annual species in rangeland communities. Weed Sci. 20:350-356.

Evans, R.A., D.A. Easi, D.N. Book, and J.A. Young. 1982. Quadratic response surface analysis of seed germination trials. Weed Sci. 30:411-416.

Evans, R.A., H.R. Holbo, R.E. Eckert, Jr., and J.A. Young. 1970. Functional environment of downy brome communities in relation to weed control and revegetation. Weed Sci. 18:154-162.

Hitchcock, A.S. 1950. Manual of grasses of the United States. Misc. Publ. 200. USDA, Washington, D. C.

Jones, T.A., D.C. Nielson, D.G. Ogle, D.A. Johnson, and S.A. Young. 1998. Registration of Sand Hollow squirreltail germplasm. Crop Sci. 38:286.
Palmquist, D.E., R.A. Evans, and J.A. Young. 1987. Comparative analysis of temperature response surfaces. pp. 97-103 In: G.W. Frasier and R. A. Evans (eds.) Seed and Seedbed Ecology of Rangeland Plants. USDA, Agr. Res. Ser., Washington, D. C.

Wilson, F.D. 1963. Revision of Sitanion (Triticeae, Gramineae). Brittonia 15:303-323.

Young, J.A. and R.A. Evans. 1977. Squirreltail seed germination. J. Range Manage. 30:33-66.

Young, J.A. and R.A. Evans. 1978. Etiolated growth of range grasses for an indication of tolerance to atrazine. Weed Sci. 26:480-483.

Young, J.A. and R.A. Evans. 1982. Temperature profiles for germination of cool season grasses. ARR-W-72, USDA, ARS, Oakland, Calif. $92 \mathrm{p}$

Young, J.A., D.E. Palmquist, and R.A. Evans. 1991. Temperature profiles for germination of big sagebrush seeds from native stands. J. Range Manage, 44:385-390.

Young, J.A., R.A. Evans, R.E. Eckert, Jr., and B. L. Kay. 1987. Cheatgrass. Rangelands 9:266-270.

Young, J.A., B.L. Kay, H. George, and R.A. Evans. 1980. Germination of three species of Atriplex. Agron. J. 72:705-709. 